\title{
Trump Presidential Survey: How Is He Doing?
}

\author{
Donald Loffredo1, Rick Harrington', Alireza Tavakkoli² \\ ${ }^{1}$ School of Arts and Sciences, University of Houston-Victoria, Victoria, USA \\ ${ }^{2}$ Department of Computer Science and Engineering, University of Nevada, Reno, USA \\ Email: loffredod@uhv.edu
}

How to cite this paper: Loffredo, D., Harrington, R. and Tavakkoli, A. (2019) Trump Presidential Survey: How Is He Doing? Open Journal of Social Sciences, 7, 238-248. https://doi.org/10.4236/jss.2019.77022

Received: June 28, 2019

Accepted: July 23, 2019

Published: July 26, 2019

Copyright $\odot 2019$ by author(s) and Scientific Research Publishing Inc. This work is licensed under the Creative Commons Attribution International License (CC BY 4.0).

http://creativecommons.org/licenses/by/4.0/

\section{(c) (i) Open Access}

\begin{abstract}
The purpose of the study was to generate a snapshot of how President Trump is doing based on the responses of 1754 participants who completed eight survey questions regarding President Trump on the 101 item National Pew September 2018 Political Survey administered by telephone. Results indicated that the survey participants viewed Donald Trump as significantly (statistically) not trustworthy, not a strong leader, someone who doesn't care about people like me, not even tempered, and not well informed. However, survey participants did view Donald Trump as significantly able to get things done, keep his promises, and stand up for what he believes in. Significantly (statistically) more males than females viewed Donald Trump as able to get things done, well informed, someone who keeps his promises, and someone who stands up for what he believes in. Republican survey participants had a statistically significant more favorable impression of Donald Trump on all eight of the survey questions than Democratic or Independent survey participants.
\end{abstract}

\section{Keywords}

Survey, US Presidential Election, Trump, Psychological Tactics, Statistics, Partisan

\section{Introduction}

Donald J. Trump has been a controversial and polarizing figure in American politics since his run for and election to the US Presidency in 2016. He has managed to build a strong base of about $40 \%$ - $41 \%$ avid supporters that has remained remarkably consistent and loyal to the present time [1]. Trump is the master brander of opponents, but he has not been as successful marketing his policies [2]. His sales and branding skills are an asset and may have helped him win the 2016 US Presidential election. According to Jason Hreha, Trump is a 
master of both active and passive persuasion [3]. Active Persuasion is tricks and gambits that one can use to get other people to do what you want [4]. For example, you might get people to sign a petition by first giving them a small gift, like a piece of candy or a flower [5]. Passive persuasion is about projecting financial, professional, and social power by, for example, driving expensive cars, buying big houses, wearing designer clothing, etc. [3].

According to Charlie Houpert in two of his YouTube videos there are twelve psychological tactics Donald Trump uses to manipulate the masses [4].

1) Sowing seeds of fear. Example: "You're gonna have more World Trade Centers. It's gonna get worse and worse, folks."

2) Provoking anger and hostility. Example: "China is taking our jobs; they're taking our money."

3) Playing the big strong messiah figure. Example: "No one else is going to keep you safe."

4) Painting everything as black and white. Example: "We are going to start winning so much that you are going to get used to winning instead of used to losing."

5) Deflection via humor. Example: When confronted by Megyn Kelly of Fox News about a statement he made in which he had called women he disliked "fat pigs, dogs, slobs, and disgusting animals," Trump stated "only Rosie O'Donnell."

6) Acting superior to opponents. Example: In one of the early GOP debates, Jeb Bush tried to point out that Trump had completely changed his stance on ISIS in a matter of only two months. Trump did not even pay Bush the courtesy of looking in his direction. "Instead, Trump looked only at the audience with an expression of disbelief and disgust that said, "Who is this guy?"

7) Doing whatever possible to make his game. Example: Trump's power plays, whether using humor in the face of criticism or acting superior to other candidates portray him as the leader of a game in which everyone else is merely a player. This ability, referred to as "frame control," is a concept in social dynamics. "Trump frames every interaction as if he is unquestionably superior to those around him, as if everyone else is in his world."

8) Creating double bind situations. Example: "I know you're trying to build up your energy, Jeb, but it's not working." In the face of such a statement, Jeb Bush can either ratchet his energy up or keep it where it is/take it down a notch. If he chooses the former, Jeb appears to be reacting to Trump, making Trump look like he is in control. If he chooses the latter, Jeb appears to remain low-energy and Trump can just steamroll over him during the debate. It is a lose/lose situation for Jeb Bush and this is the power of a double-bind situation.

9) Repetition. Example: The second of Charlie Houpert's videos "shows one absurd clip in which Trump manages to say the word 'win' 12 times in about 15 seconds."

10) Social Proof. As social creatures, people tend to do and believe whatever they think everyone else is doing and believing. Trump understands the impor- 
tance of this and so he acts as if he has an army of people behind him. Example: stating endorsements like "everyone knows that."

11) Appeals to authority. Example: Trump actually loves to assert that authority figures approve of him and disapprove of other candidates and competitors. The second video of Charlie Houpert's cites Trump saying, "Larry Kudlow likes my tax plan," and "Experts wonder if Cruz can run the US because he was born in Canada."

12) Appeals to irrational parts of our brains. Trump understands that most people make decisions based on emotion rather than on reason. He also understands and exploits certain methods of manipulating people's emotions to get them to do what he wants. Example: Most of the psychological techniques mentioned above are effective in making people feel very confident about a position even if they have not considered any statistical evidence or rational arguments.

Since elected President of the United States, Trump's popularity has fluctuated though he has been able to keep an approval rating of around 40\% - 41\% [1]. Much of the President's behavior has been a topic of discussion recently and some of his actions have alarmed House Democrats, the Media, and fellow Americans. Many Democrats in the U.S. House of Representatives and members of the America Media are calling for an impeachment inquiry or impeachment of President Trump as soon as possible although House Speaker Nancy Pelosi has been reluctant to approve initiation of an impeachment inquiry. Recent polls by Trump's own pollsters have indicated that as of June 17, 2019 many Democratic contenders are beating him in many states he needs to carry to be reelected in 2020 [5].

A study by Shockley-Zalabak. Morreale, and Stavrositu (2017) which explored voters' perception of Hillary Clinton and Donald Trump "confirmed relatively low-trust levels for both Hillary Clinton and Donald Trump and an electorate divided demographically about the trust in the two candidates [6]." In a second survey in the same study by the same authors Trump scored significantly (statistically) higher than Clinton in openness and honesty [6]. Clinton and Trump were trusted equally in dealing with the U.S. economy and jobs, but Trump was trusted more in dealing with terrorism and national security while Clinton was trusted more in dealing with health care [6]. In a survey of 1500 adults in January 2019 about $58 \%$ of the participants indicated that "they trust what Trump says less than previous presidents [7]." This was a 7-point increase since Trump took office in February 2017 [7]. In the same study, 59\% of the participants said that the Trump administration's ethical standards were "not good or poor [7]." In a stark partisan contrast $94 \%$ of the Democratic participants indicated that they trusted President Trump's statements less than previous presidents while 58\% of Republican participants stated they trusted Trump's statements more [7]. The purpose of this study was to generate a snapshot of how President Trump is doing on key questions regarding his perceived performance as president since the 2020 U.S. Presidential election is approaching. 


\section{Method}

\subsection{Participants}

The National Pew September 2018 Political Survey was administered to 1754 participants by telephone in two forms on two separate administrations. Question 1 - 4 below were in Form 1 and administered to 867 participants (463 male, 404 female) with an average age of 53.41 years and a standard deviation of 19.37 years. Questions 5 - 8 were in Form 2 and administered to 887 participants (505 male, 382 female) with an average age of 53.52 years and a standard deviation of 19.1 years. The participants ranged in age from 18 to 100 years or higher in Form 1 and 18 to 100 years in Form 2. In Form 1 about 72.1\% of the participants were White non-Hispanic, 5\% Black non-non-Hispanic, 12.1\% Hispanic, 7\% Other, 3.8\% Don't know/Refused. In Form 2 about 70.3\% of the participants were White non-Hispanic, 7.1\% Black non-non-Hispanic, 12.7\% Hispanic, 7\% Other, 6.8\% Don't know/Refused. The age distributions for Form 1 and Form 2 are below. The political party affiliation of participants was $27.5 \%$ Republican, $31.5 \%$ Democrat, $36.1 \%$ Independent, no preference $2.1 \%$, other party $0.6 \%$, and Don't know/Refused 2.1\% (Table 1).

\subsection{Survey Questions}

Eight survey questions regarding President Trump were used from the National Pew September 2018 Political Survey. All questions began with: As I read some pairs of opposite phrases, please tell me which one best reflects your impression of Donald Trump.

Table 1. Education level. What is the highest level of school you have completed or the highest degree you have received?

\begin{tabular}{lcc}
\hline & Frequency & Percent \\
\hline Less than high school (Grades 1-8 or no formal schooling) & 45 & 2.6 \\
$\begin{array}{l}\text { High school incomplete (Grades 9-11 or Grade 12 with } \\
\text { NO diploma) }\end{array}$ & 45 & 2.6 \\
$\begin{array}{l}\text { High school graduate (Grade 12 with diploma or GED } \\
\text { certificate) }\end{array}$ & 335 & 19.1 \\
$\begin{array}{l}\text { Some college, no degree (includes some community college } \\
\text { Two year associate degree from a college or university }\end{array}$ & 273 & 15.6 \\
$\begin{array}{l}\text { Four year college or university degree/Bachelor's degree } \\
\text { (e.g., BS, BA, AB) }\end{array}$ & 223 & 12.7 \\
$\begin{array}{l}\text { Some postgraduate or professional schooling, no } \\
\text { postgraduate degree (e.g. some graduate school) }\end{array}$ & 469 & 26.7 \\
$\begin{array}{l}\text { Postgraduate or professional degree, including master's, } \\
\text { doctorate, medical or law degree }\end{array}$ & 156 & 195 \\
$\begin{array}{l}\text { (VOL) Don't know/Refused } \\
\text { Total }\end{array}$ & 134 \\
\hline
\end{tabular}




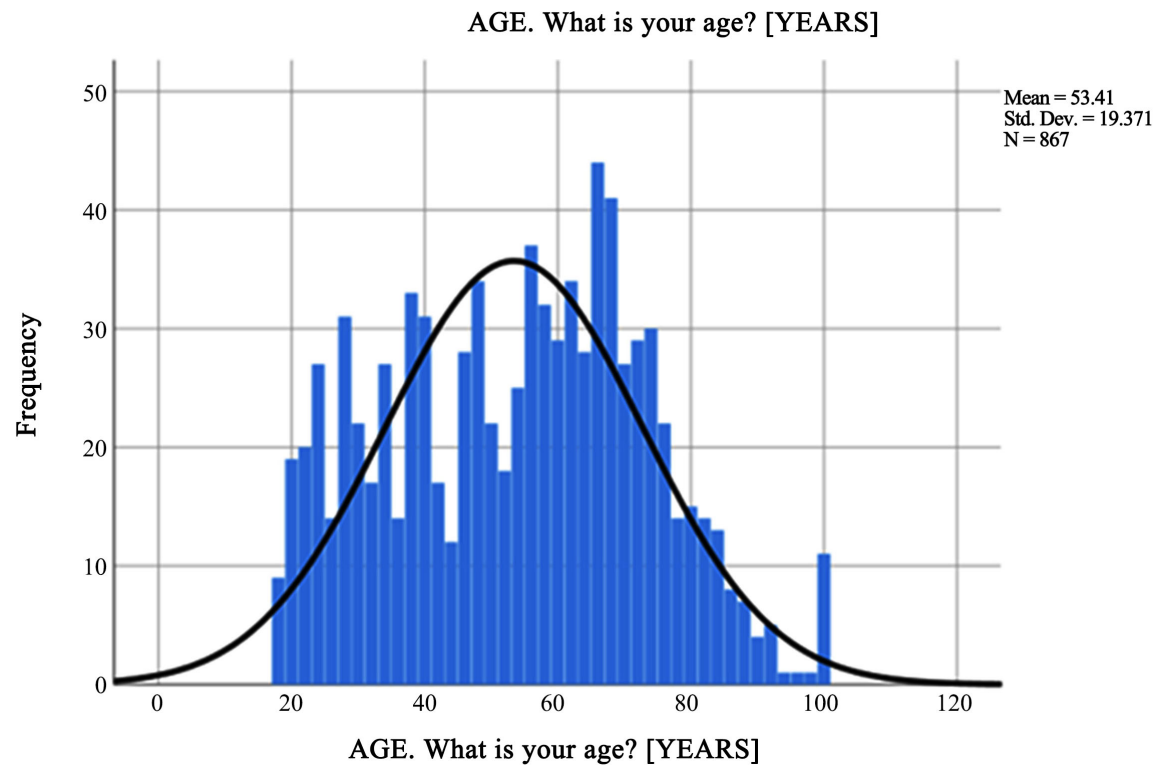

Form 1. Participant age distribution.

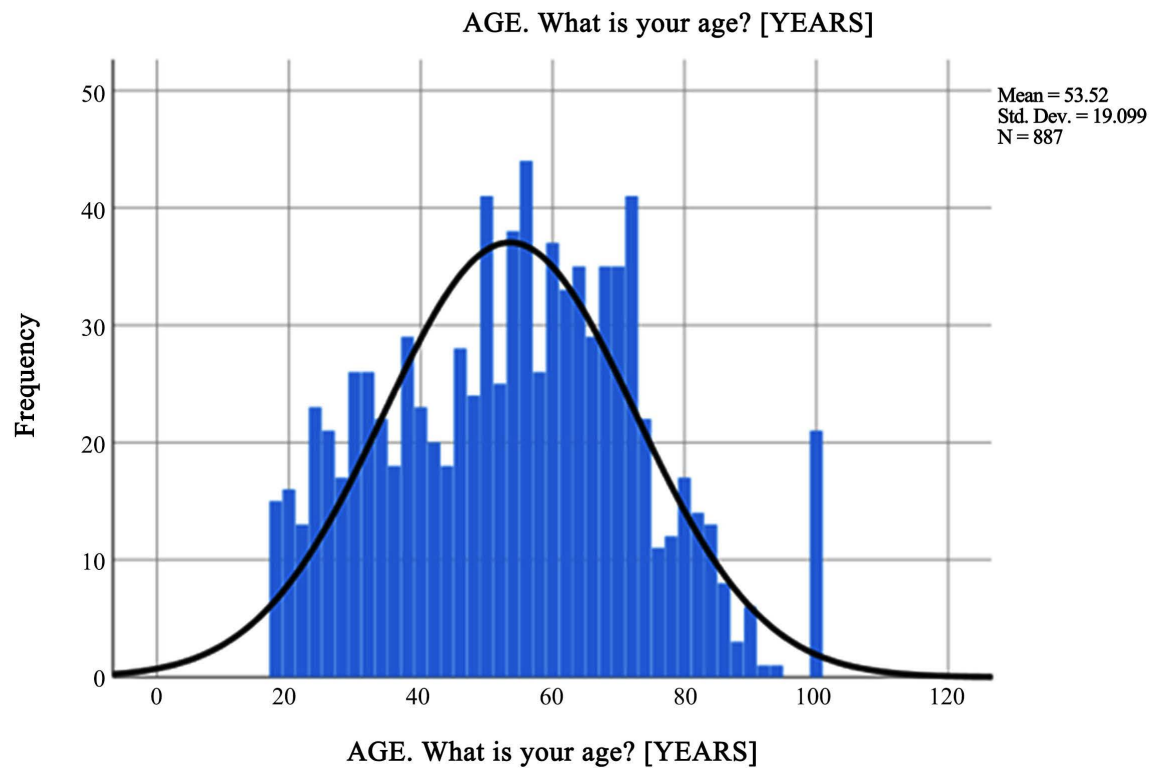

Form 2. Participant age distribution.

1) Trustworthy or not trustworthy.

2) Able to get things done or not able to get things done.

3) A strong leader or not a strong leader.

4) Someone who cares about people like me or someone who doesn't care about people like me.

5) Even tempered or not even tempered.

6) Well informed or not well informed.

7) Keeps his promises or doesn't keep his promises.

8) Someone who stands up for what he believes in or someone who doesn't stand up for what he believes in. 
For each of the eight questions above two additional responses were available to participants:

- Neither particularly

- Don't know/Refused

The Pew Research Center makes datasets available to approved researchers and the eight questions used in this study was a small subset of the 101 questions asked on the National PEW 2018 Political Survey.

\subsection{Procedure}

The National Pew September 2018 Political Survey of 101 questions was individually administered by telephone (439 landline, 1315 cell phone) to 1754 participants (from all 50 states) in two forms or separate administrations during September 18-24, 2018. There were 554 male (31.6\%) and 1200 female (68.4\%) interviewers who administered the survey by telephone.

\subsection{Statistical Analysis}

The SPSS data set for the entire National Pew September 2018 Political Survey was downloaded from https://www.people-press.org/?post_type=dataset in June 2019 with permission and approval of the Pew Research Center. Descriptive statistics, chi-square tests for goodness of fit, and chi-square tests for independence were used to analyze the eight survey question answers regarding President Trump.

\section{Results}

Table 2. Question 1. As I read some pairs of opposite phrases, tell me which one best reflects your impression of Donald Trump. Trustworthy or not trustworthy?

The participants showed a significant preference for the not trustworthy impression of Donald Trump, $\chi^{2}(3, \mathrm{n}=867)=811.39, \mathrm{p}<0.001$. A chi-square test for independence indicated that there was no significant difference by gender on Question $1, \chi^{2}(3, \mathrm{n}=867)=6.30, \mathrm{p}=0.098$. Not surprisingly, a chi-square test for independence revealed that there was a significant difference by political party (Republican, Democrat, or Independent) on Question 1 with significantly more Republican participants (197) than Democratic participants (10) or Independent participants (103) viewing Donald Trump as trustworthy, $\chi^{2}(2, \mathrm{n}=$ 794) $=351.18, \mathrm{p}<0.001$ (Table 3 ).

The participants showed a significant preference for the able to get things done impression of Donald Trump, $\chi^{2}(3, \mathrm{n}=867)=744.35 \mathrm{p}<0.001$. A chi-square test for independence indicated that there was a significant difference by gender on Question 2 with more males than females viewing Donald Trump as able to get things done, $\chi^{2}(3, \mathrm{n}=867)=13.16, \mathrm{p}=0.004$. A chi-square test for independence revealed that there was a significant difference by political party (Republican, Democrat, or Independent) on Question 2 with significantly more Republican participants (215) than Democratic participants (39) or Independent 
participants (177) viewing Donald Trump as able to get things done, $\chi^{2}(2, \mathrm{n}=$ 792) $=295.03, \mathrm{p}<0.001($ Table 4$)$.

The participants showed a significant preference for the not a strong leader impression of Donald Trump, $\chi^{2}(3, n=867)=783.32, p<0.001$. A chi-square test for independence could not be used to see if there was a significant difference by gender because two cells had an expected value less than 5 . A chi-square test for independence revealed that there was a significant difference by political party (Republican, Democrat, or Independent) on Question 3 with significantly more Republican participants (209) than Democratic participants (28) or Independent participants (144) viewing Donald Trump as A strong leader, $\chi^{2}(2, \mathrm{n}=$ $805)=305.83, \mathrm{p}<0.001($ Table 5$)$.

Table 2. Question 1. As I read some pairs of opposite phrases, tell me which one best reflects your impression of Donald Trump. Trustworthy or not trustworthy?

\begin{tabular}{ccc}
\hline & Observed N & Expected N \\
\hline Trustworthy & 321 & 216.8 \\
Not trustworthy & 510 & 216.8 \\
Neither particularly & 17 & 216.8 \\
Don't know/Refused & 19 & 216.8 \\
Total & 867 & \\
\hline
\end{tabular}

Table 3. Question 2. As I read some pairs of opposite phrases, tell me which one best reflects your impression of Donald Trump. Able to get things done or not able to get things done?

\begin{tabular}{ccc}
\hline & Observed N & Expected N \\
\hline Able to get things done & 456 & 216.8 \\
Not able to get things done & 375 & 216.8 \\
Neither particularly & 13 & 216.8 \\
Don't know/Refused & 23 & 216.8 \\
Total & 867 & \\
\hline
\end{tabular}

Table 4. Question 3. As I read some pairs of opposite phrases, tell me which one best reflects your impression of Donald Trump. A strong leader or not a strong leader?

\begin{tabular}{ccc}
\hline & Observed N & Expected N \\
\hline A Strong Leader & 397 & 216.8 \\
Not a Strong Leader & 447 & 216.8 \\
Neither Particularly & 8 & 216.8 \\
Don't Know/Refused & 15 & 216.8 \\
Total & 867 & \\
\hline
\end{tabular}


Table 5. Question 4. As I read some pairs of opposite phrases, tell me which one best reflects your impression of Donald Trump. Someone who cares about people like me or someone who doesn't care about people like me?

\begin{tabular}{ccc}
\hline & Observed N & Expected N \\
\hline Cares about people like me & 342 & 216.8 \\
Doesn't Care about people like me & 492 & 216.8 \\
Neither Particularly & 10 & 216.8 \\
Don't Know/Refused & 23 & 216.8 \\
Total & 867 & \\
\hline
\end{tabular}

The participants showed a significant preference for the someone who doesn't care about people like me impression of Donald Trump, $\chi^{2}(3, \mathrm{n}=867)=$ 792.317, $\mathrm{p}<0.001$. A chi-square test for independence could not be used to see if there was a significant difference by gender because one cell had an expected value less than 5. A chi-square test for independence revealed that there was a significant difference by political party (Republican, Democrat, or Independent) on Question 4 with significantly more Republican participants (200) than Democratic participants (16) or Independent participants (114) viewing Donald Trump as someone who cares about people like me, $\chi^{2}(2, \mathrm{n}=796)=328.13, \mathrm{p}<$ 0.001 (Table 6).

The participants showed a significant preference for the not even-tempered impression of Donald Trump, $\chi^{2}(3, \mathrm{n}=887)=1098.06, \mathrm{p}<0.001$. A chi-square test for independence indicated that there was no significant difference by gender on Question 5, $\chi^{2}(3, \mathrm{n}=887)=3.16, \mathrm{p}=0.368$. A chi-square test for independence revealed that there was a significant difference by political party (Republican, Democrat, or Independent) on Question 5 with significantly more Republican participants (126) than Democratic participants (21) or Independent participants (53) viewing Donald Trump as Even Tempered, $\chi^{2}(2, n=800)=$ 159.81, $\mathrm{p}<0.001$ (Table 7).

The participants showed a significant preference for the not well-informed impression of Donald Trump, $\chi^{2}(3, \mathrm{n}=887)=750.80, \mathrm{p}<0.001$. A chi-square test for independence indicated that there was a significant difference by gender on Question 6 with more males than females viewing Donald Trump as well informed, $\chi^{2}(3, \mathrm{n}=887)=19.29, \mathrm{p}<0.001$. A chi-square test for independence revealed that there was a significant difference by political party (Republican, Democrat, or Independent) on Question 6 with significantly more Republican participants (206) than Democratic participants (24) or Independent participants (116) viewing Donald Trump as Well informed, $\chi^{2}(2, \mathrm{n}=807)=324.01, \mathrm{p}$ $<0.001$ (Table 8).

The participants showed a significant preference for the does keep his promises impression of Donald Trump, $\chi^{2}(3, \mathrm{n}=867)=689.63, \mathrm{p}<0.001$. A chi-square test for independence indicated that there was a significant difference by gender on Question 7 with more males than females viewing Donald Trump 
as someone who keeps his promises, $\chi^{2}(3, \mathrm{n}=887)=19.03, \mathrm{p}<0.001$. A chi-square test for independence revealed that there was a significant difference by political party (Republican, Democrat, or Independent) on Question 7 with significantly more Republican participants (225) than Democratic participants (59) or Independent participants (160) viewing Donald Trump as someone who keeps his promises, $\chi^{2}(2, \mathrm{n}=798)=281.72, \mathrm{p}<0.001$ (Table 9).

Table 6. Question 5. As I read some pairs of opposite phrases, tell me which one best reflects your impression of Donald Trump. Even tempered or not even tempered?

\begin{tabular}{ccc}
\hline & Observed N & Expected N \\
\hline Even Tempered & 208 & 221.8 \\
Not Even Tempered & 629 & 221.8 \\
Neither Particularly & 21 & 221.8 \\
Don't Know/Refused & 29 & 221.8 \\
Total & 887 & \\
\hline
\end{tabular}

Table 7. Question 6. As I read some pairs of opposite phrases, tell me which one best reflects your impression of Donald Trump. Well informed or not well informed?

\begin{tabular}{ccc}
\hline & Observed N & Expected N \\
\hline Well Informed & 359 & 221.8 \\
Not Well Informed & 483 & 221.8 \\
Neither Particularly & 22 & 221.8 \\
Don't Know/Refused & 23 & 221.8 \\
Total & 887 & \\
\hline
\end{tabular}

Table 8. Question 7. As I read some pairs of opposite phrases, tell me which one best reflects your impression of Donald Trump. Keeps his promises or doesn't keep his promises?

\begin{tabular}{ccc}
\hline & Observed N & Expected N \\
\hline Keeps his promises & 456 & 221.8 \\
Doesn't keep his promises & 374 & 221.8 \\
Neither Particularly & 19 & 221.8 \\
Don't Know/Refused & 38 & 221.8 \\
Total & 887 & \\
\hline
\end{tabular}

Table 9. Question 8. As I read some pairs of opposite phrases, tell me which one best reflects your impression of Donald Trump. Someone who stands up for what he believes in or someone who doesn't stand up for what he believes in?

\begin{tabular}{ccc}
\hline & Observed N & Expected N \\
\hline Stands up for what he believes in & 608 & 221.8 \\
Doesn't stand up for what he believes in & 220 & 221.8 \\
Neither Particularly & 18 & 221.8 \\
Don't Know/Refused & 41 & 221.8 \\
Total & 887 & \\
\hline
\end{tabular}


The participants showed a significant preference for the someone who stands up for what he believes impression of Donald Trump, $\chi^{2}(3, \mathrm{n}=867)=1007.34$, $\mathrm{p}<0.001$. A chi-square test for independence indicated that there was a significant difference by gender on Question 8 with more males than females viewing Donald Trump as someone who stands up for what he believes in, $\chi^{2}(3, \mathrm{n}=887)$ $=8.52, \mathrm{p}=0.036$. A chi-square test for independence revealed that there was a significant difference by political party (Republican, Democrat, or Independent) on Question 8 with significantly more Republican participants (235) than Democratic participants (145) or Independent participants (206) viewing Donald Trump as someone who stands up for what he believes in, $\chi^{2}(2, \mathrm{n}=792)=$ 114.37, $\mathrm{p}<0.001$.

\section{Discussion}

The results indicated that the survey participants viewed Donald Trump as significantly (statistically) not trustworthy, not a strong leader, someone who doesn't care about people like me, not even tempered, and not well informed. However, participants did view Donald Trump as significantly (statistically) able to get things done, keep his promises, and Stand up for what he believes in. Significantly (statistically) more males than females viewed Donald Trump as able to get things done, well informed, someone who keeps his promises, and someone who stands up for what he believes in. Not surprisingly, Republican survey participants had a statistically significant more favorable impression of Donald Trump on all eight survey questions than Democratic or Independent survey participants. The extreme differences between Democrat and Republican survey participants on the eight survey questions mirrors the seemingly growing animosity between the two political parties over the Trump presidency and just about every other political issue. The social and political implications of this study are that President Trump appears to be a polarizing figure to the American electorate with Republicans widely approving of him and Democrats widely disapproving of him. Trump's foreign policy is at odds with traditional allies of the United States and Trump's international ratings remain low, especially with key allies [8].

Table 10. US population percentages July 1, 2018.

\begin{tabular}{cc}
\hline Race and Hispanic Origin & Percentage \\
White alone & $76.6 \%$ \\
Black or African American alone & $13.4 \%$ \\
American Indian and Alaskan native alone & $1.3 \%$ \\
Asian alone & $5.8 \%$ \\
Native Hawaiian and Other Pacific Islander alone & $0.2 \%$ \\
Two or more Races & $2.7 \%$ \\
Hispanic or Latino, percent & $18.1 \%$ \\
White alone, not Hispanic or Latino & $60.7 \%$ \\
\hline
\end{tabular}




\section{Conclusion}

Although the data for this survey came from a national US sample of 1754 participants, approximately $71 \%$ of the sample was White non-Hispanic. Future surveys should include larger sample sizes and match current population percentages of the US population indicated below. Some chi-square tests for independence analyses (survey questions 3 and 4) could not be used because some cells were less than 5 as a result of few participants in one or more categories of a survey question. As of July 1, 2018, the US population percentages were as expressed in Table 10 [9].

\section{Conflicts of Interest}

The authors declare no conflicts of interest regarding the publication of this paper.

\section{References}

[1] Meet the Press Television Show. Aired on NBC June 16, 2019.

[2] Badger, E. and Quealey, K. (2017) New York Times. The Upshot July 18, 2017. https://www.nytimes.com/interactive/2017/07/18/upshot/trump-seems-much-bette r-at-branding-opponents-than-at-marketing-policies.html

[3] Hreha, J. (2016) How Donald Trump Won. It's All about Psychology. Here's His Playbook.

https://www.nytimes.com/interactive/2017/07/18/upshot/trump-seems-much-bette r-at-branding-opponents-than-at-marketing-policies.html

[4] Highexistence.com. 12 Psychological Tactics Donald Trump Uses to Manipulate the Masses. Based on Youtube Videos by Charlie Houpert.

https://highexistence.com/12-psychological-tactics-donald-trump-uses-to-manipula te-the-masses

[5] Wise, J. (2019) Trump Hits Polling on Fox News: Something Weird Going on at Fox.

https://thehill.com/homenews/campaign/448994-trump-hits-polling-on-fox-news-s omething-weird-going-on-at-fox

[6] Shockley-Zalabak, P.S., Morreale, S.P. and Stavrositu, C. (2017) Voters' Perception of Trust in 2016 Presidential Candidates, Clinton and Trump: Exploring the Election's Outcome. American Behavioral Scientist, 63, 856-887. https://doi.org/10.1177/0002764217730855

[7] Palmer, J. (2019) Poll: Trump Starts Third Year with Low Public Trust. https://www.courthousenews.com/poll-trump-starts-third-year-with-low-public-tru st

[8] Wike, R., Stokes, B., Poushter, J., Silver, L., Fetterolf, J. and Devlin, K. (2019) Trump's International Ratings Remain Low, Especially among Key Allies. Pew Research Center, Washington DC, 1-9.

[9] United States Census Bureau Quick Facts. https://www.census.gov/quickfacts/fact/table/US/IPE120217 